\title{
Effect of Microbial Transglutaminase on the quality of Frozen Surimi Made from Various Kinds of Fish Species
}

\author{
Takashi Asagami, ${ }^{* 1}$ Masaaki Ogiwara, ${ }^{* 1}$ Atsushi Wakameda, ${ }^{* 2}$ and Satoshi F. Noguchi*2, \\ ${ }^{* 1}$ Engineering Department, Maruha Co., Ltd., Otemachi, Chiyodaku, Tokyo, Japan 100 \\ *2Food Research Laboratory, Central Research Institute, Maruha Co., Ltd., Wadai, Tsukuba, Ibaraki 300-42 Japan \\ (Received June 21, 1994)
}

\begin{abstract}
The effects of microbial transglutaminase (MTGase) on fish muscles of seven kinds of fish-species were studied to increase the basic knowledge of the preparation of the high quality frozen surimi. Because of the full consideration of application, all tested samples were prepared in the surimi plants with the commercial manufacturing process. The textural properties of each surimi gel were measured by a punch force and punch deformation. The condition of setting was defined at $30 \mathrm{C}$ and for $60 \mathrm{~min}$. The accuracy of the data of the punch test was investigated by using the coefficient values of variation. The effects of MTGase on surimi gel varied with each fish species. The values of the punch force of all tested surimi gels increased with the addition of MTGase, but the values of punch deformation decreased with an addition of over $0.03 \%$ MTGase in general. Since, the value of the punch deformation is highly appraised by Kamaboko makers more than the punch force, about $0.03 \%$ of MTGase $(1.1 \mathrm{unit} / \mathrm{mg}$ powder used) were recommended for the desirable concentration in the frozen surimi processing. However, there is a recognizable differences in the two kinds of walleye pollock surimi. The results show that the increasing effect of MTGase is not only controlled by the fish species but also by more complicated factors such as freshness of the raw fish.
\end{abstract}

Key words: frozen surimi, transglutaminase, texture, setting, fish species

Two major research investigations have been made to improve the quality of frozen surimi. One is the study on the cryostabilization of protein in surimi. The other is the development of techniques related with the improvement of the functional properties of surimi gel. Chemical and physical bonding on the formation of the gelled protein network is the key technology for the latter, and our present trial will be classified into the latter technique. Using the results of these investigations," considerable research has been expended on the formation of bonds of protein network for the improvement of the function of Kamaboko gel. For, example, Okada ${ }^{2)}$ reported the increasing effect of potassium bromate, which is an oxidant that accelerates the intermolecular disulfide bonds of muscle proteins on the surimi gel formation. Potassium bromate as food additives had been permitted for the kamaboko making in Japan until 1982. As Simidu ${ }^{3)}$ had suggested that the enzymatic reaction take part in the setting of surimi, the formation of inter- and intra-molecular bonds by enzyme is another hopeful reaction which will be more readily accepted by regulatory authorities and the consumer from the view point of safety. One enzyme of potential use in the food industry is transglutaminase, such as the mammalian transglutaminase (EC 2.3.2.13), which is capable of introducing covalent crosslinks between protein molecules and various related reported papers. ${ }^{4-15)}$ Recently, the new type of transglutaminase was purified from the culture filtrate of streptoverticillium. ${ }^{20}$ ) Mass production of $\mathrm{Ca}^{2+}$-independent microbial transglutaminase (MTGase) enable the industrial and practical use of MTGase for the food processing now. More recently, some studies on the application of MTGase, and on the polymerization of several proteins have been reported. ${ }^{16-19)}$ However, study on the industrial use of MTGase for the frozen surimi processing has not-been reported yet.

The objective of present study was to test the use of MTGase on the frozen surimi to extend a basic knowledge for preparing high quality frozen surimi. On the other side, in the processing of Japanese fishery products, the species-specificity is regarded as of major importance by not only the technologists in the plants but also fishery scientists. The seven kinds of fish species which are commonly used in the commercial surimi production were selected as the test samples in the sense of the comparative study of the fish species. The characteristics or special merits of the present research were that all tested surimi samples were prepared in commercial plants with the general surimi manufacturing process in full consideration of the practical application.

\section{Materials and Methods}

Enzyme Powdered microbial transglutaminase (1.1 units $/ \mathrm{mg}$ ), prepared from the culture of storeptoverticillium sp. by the method of Ando et al.,$^{20)}$ was obtained from the central reseach laboratory of Ajinomoto $\mathrm{Co}$., Inc. (Tokyo, Japan). Enzyme activity was measured by the hydroxamate procedure with CBZ-L-glutaminyl glycine by the method of Folk and Cole. ${ }^{21)}$ The enzyme activity was defined as one unit causing the formation $1 \mu \mathrm{M}$ of

\footnotetext{
$\uparrow$ To whom offprint requests should be addressed.
} 
hydroxamic acid/minute. $\mathrm{Ca}^{2+}$ concentration of the used MTGase powder is $0.063 \%$, and there is no addition of $\mathrm{Ca}^{2+}$ to the enzyme powder.

\section{Preparation of Surimi with Microbial Transglutaminase}

All tested surimi samples were prepared on the factory ship or shore plants according to the general and commercial surimi manufacturing process reported by Toyoda et $a .^{22)}$ Powder of microbial transglutamminase was blended with cryoprotectants and mixed with the washed and dehydrated fish meat in the silent cutter. After mixing, $10 \mathrm{~kg}$ surimi was, packed into a polyethylene bag and frozen with a contact freezer to a center temperature of $-25^{\circ} \mathrm{C}$. After the freezing was completed, surimi samples were packaged in the corrugated cardboard carton. The frozen surimi samples were stored at $-25^{\circ} \mathrm{C}$ or below during holding and shipping, until the measurements of functional properties could be made.

Walleye pollock Theragre chalcogramma was harvested at the Hokkaido coast in February, stored in the vessel with ice and unloaded within 2 weeks of capture. Fillets were processed into surimi in the local surimi processing plant at Monbetsu, Hokkaido, Japan. Surimi samples were made with $4 \%$ sucrose, $4 \%$ sorbitol, and $0.25 \%$ polyphosphate.

For the preparation of high grade surimi sample, walleye pollock were harvested by a factory ship in the Bering sea in October. Eleven hours after harvesting, fillets were processed into surimi by the general and commercial processing methods. Surimi samples were made with $4 \%$ sucrose, $4 \%$ sorbitol, and $0.25 \%$ polyphosphate.

Southern blue whiting Micromesistirns australis was harvested off the coast of South Islands of New Zealand, by a factory trawler, and in September. Ten hr after harvesting, the fillets were processed into surimi by the commercial processing methods. Surimi samples were made with $4 \%$ sucrose, $4 \%$ sorbitol and $0.25 \%$ polyphosphate.

White croaker Argyrosomus argentatus, largehead hairtail Trichiurus lepturus, lizard fish Saurida undosyuamis, bigeyes Priacanthus macracanthus, and hachibiki Erythrocles schlegelii were harvested in the East China Sea in February. In the trawler, raw fish were stored in a wooden box with ice and unloaded within a week of capture. Fillets of these fish species were processed into surimi in a local surimi processing plant at Nagasaki, east part of Japan. Surimi samples of these species without white croaker were made with $4 \%$ sucrose, $4 \%$, sorbitol, $3 \%$ liquid egg white, and $0.2 \%$ polyphosphate. White croaker surimi was made with $4 \%$ sucrose and $4 \%$ sorbitol.

\section{Surimi Gel Preparation}

Three months after the day of sample preparation, surimi packages were removed from frozen storage and kept at room temperature to reach $-5^{\circ} \mathrm{C}$. Samples ware chopped and placed in a bowl of silent cutter, then salt equal to $3 \%$ of surimi was added, and blended into the surimi' paste. About $150 \mathrm{~g}$ the surimi paste was packed into a $48 \mathrm{~mm}$ diameter folded vinylidene chloride film, and bound on both ends. The filled tubes were incubated (set) at $30^{\circ} \mathrm{C}$ for $60 \mathrm{~min}$. to a final heating (cook) at $90^{\circ} \mathrm{C}$ for $20 \mathrm{~min}$. Cooked gels were cooled in an ice-water bath and stored in a cold room $\left(5^{\circ} \mathrm{C}\right)$ overnight prior to the punch test.

Measurement of the Jelly Strength by Punch Test

Test samples were allowed to reach room temperature, cut into round-shaped slices of $25 \mathrm{~mm}$ height, then removed from film and used as a test specimen. The breaking force strength or punch force $(\mathrm{g})$ and the depths of depression or punch deformation $(\mathrm{mm})$ were measured using RHEO TEX (Sun science Co., LTD, Japan) with a spherical plunger ( $5 \mathrm{~mm}$ diameter).

\section{Results}

\section{Walleye Pollock Surimi}

Tests were run on the two kinds of walleye pollock suri$\mathrm{mi}$, namely land-processed and ship-processed samples. The changes in two textural properties, punch force, and punch deformation, as the results of several concentrations of MTGase are shown in the Figs. 1 and 2. The textural properties of the land-processed walleye pollock surimi gel is shown in Fig. 1. Moisture of the land-processed walleye pollock surimi was $77.4 \%$ and $\mathrm{pH}$ was 7.30 . The textural values that changed depended greatly on the concentration of MTGase. The punch force increased with the concentration of MTGase, and at the concentration of $0.03 \%$ MTGase the value of the punch force increased from $550 \mathrm{~g}$ to $1250 \mathrm{~g}$. However, more increases of the punch force were not determined even if adding over $0.03 \%$ of MTGase. On the other hand, the values of punch deformation increased slightly at $0.3 \%$ MTGase but decreased at higher concentrations. The changes of textural properties of ship-processed MTGase added surimi are shown in Fig. 2. Moisture of the ship-processed surimi sample was $73.7 \%$ and $\mathrm{pH} 7.30$. The punch force increased gradually with the concentration of MTGase, and at the concentration of $0.06 \%$ MTGase the values of the punch force, increased from $1149 \mathrm{~g}$ to $1536 \mathrm{~g}$. However, higher increases of the punch force were not found even if over $0.06 \%$ of MTGase were added. The values of punch

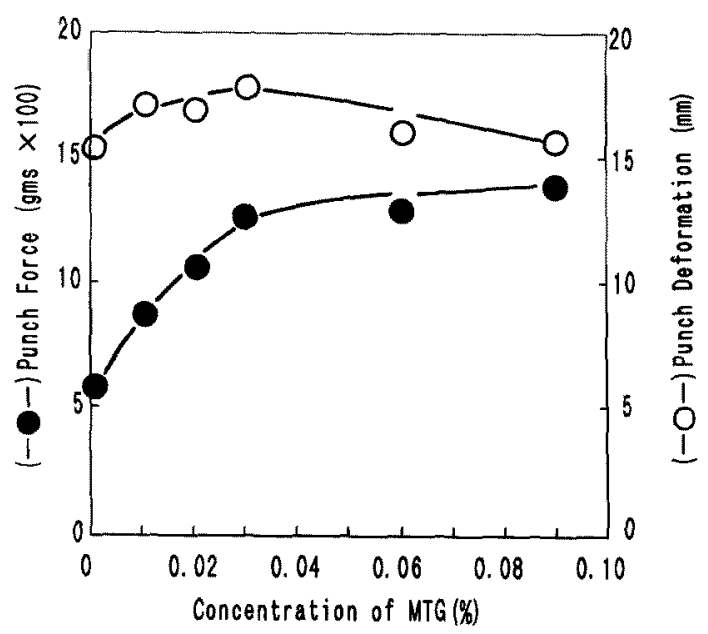

Fig. 1. Functional properties of land-processed walleye pollock surimi gels produced at different enzyme concentrations.

Closed circle indicates the punch force and open circle indicates punch deformation. 


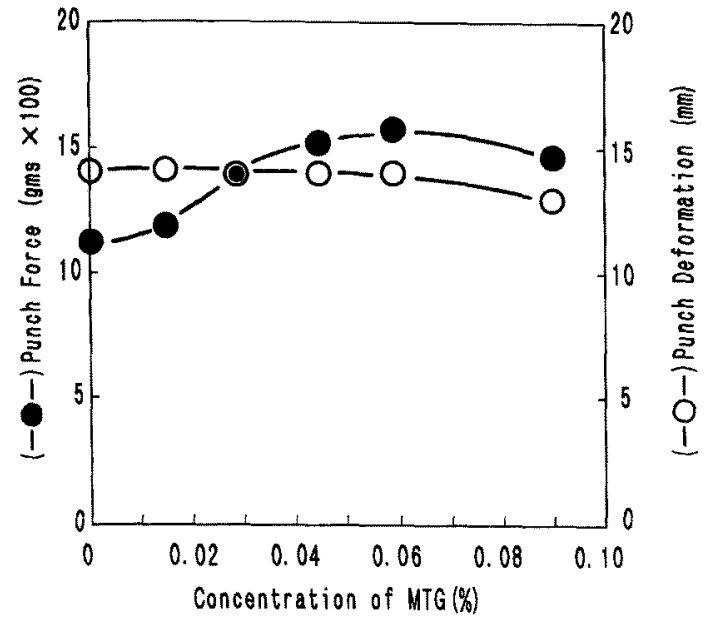

Fig. 2. Functional properties of ship-processed walleye pollock surimi gels produced at different enzyme concentrations.

deformation did not change with the concentration of MTGase.

\section{White Croaker Surimi}

Moisture of the white croaker surimi was $77.58 \%$ and $\mathrm{pH}$ 7.16. The changes of two textural limits as a result of using several concentrations of MTGase to croaker surimi is shown in Fig. 3. The values of the punch force increased gradually with, the concentration of MTGase, but the Value at $0.09 \%$ of MTGase was limited under $1000 \mathrm{~g}$. The values of punch deformation did not change with the concentration of MTGase. The quality of white croaker used in the present preparation is assumed in the intermediate grade as not high from the results of MTGase free surimi.

\section{Bigeye Surimi}

Moisture of the bigeye surimi was $77.86 \%$ and $\mathrm{pH} 7.59$. The change of two textural limits was the result of using several concentrations of MTGase to bigeye surimi is

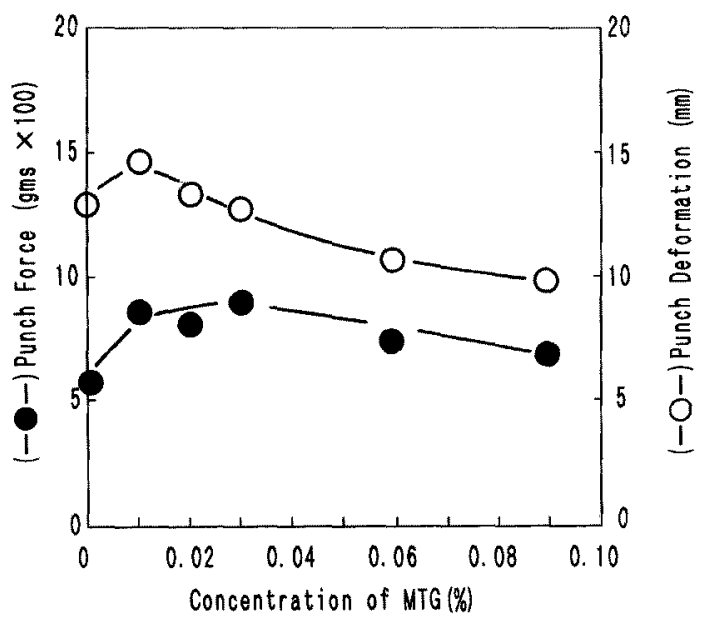

Fig. 4. Functional properties of bigeye surimi gels produced at different enzyme concentrations.

shown in Fig. 4. The values of the punch force increased from $550 \mathrm{~g}$ MTGase free samples to $880 \mathrm{~g}$ at $0.03 \%$ MTGase, but decreased at higher concentrations. The values, of punch deformation increased from 0 to $0.01 \%$ MTGase, but decreased slightly at higher concentration slightly.

\section{Lizard Fish Surimi}

Moisture of the lizard fish suriml was $78.7 \%$ and $\mathrm{pH}$ 7.42. The changes of two textural limits as a result of using several concentrations of MTGase to lizard fish surlmi is, shown in Fig. 5. The values of the punch force increased slightly from $800 \mathrm{~g}$, MTGase free sample, to $1100 \mathrm{~g}$, $0.06 \%$ of MTGase, and did not changed at higher concentrations. The values of punch deformatlon did not change from 0 to $0.01 \%$ MTGase and decreased at higher concentrations.

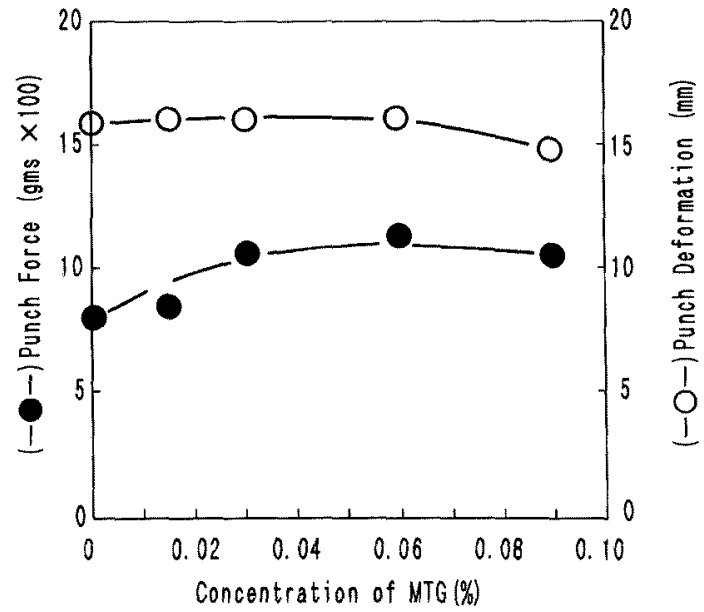

Fig. 5. Functional properties of lizard fish surimi gels produced at different enzyme concentrations.
Fig. 3. Functional properties of croaker surimi gels produced at different enzyme concentrations.

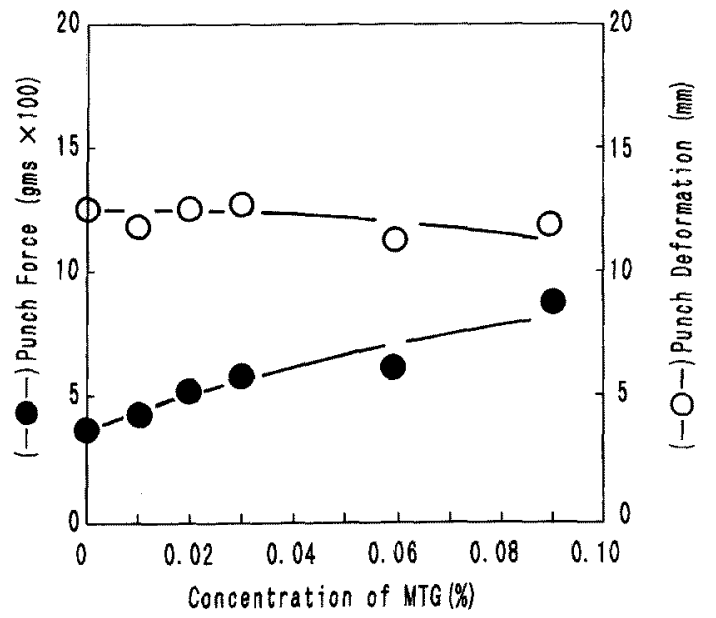




\section{Largehead Hairtail Surimi}

Moisture of the largehead hairtail surimi was $77.27 \%$ and $\mathrm{pH}$ 7.53. The changes of two textural lmits as a result of using several concentrations of MTGase to largehead hairtail surimi is shown in Fig. 6. The values of the punch force increased slightly with the addition of MTGase. The values of punch deformation did not change in the low concentration of MTGase, from 0 to $0.03 \%$, but decreased at higher concentrations.

\section{Hachibiki Surimi}

Moisture of the tested himedai surimi was $79.3 \%$ and $\mathrm{pH}$ 7.28. The changes of two textural limits as a result of using several concentrations of MTGase to hachibiki suri$\mathrm{mi}$, is shown in Fig. 7. Little increase of the punch force was determined with the addition of MTGase. The values of punch deformation decreased from 0 to $0.03 \%$ MTGase and did not change at higher concentrations.

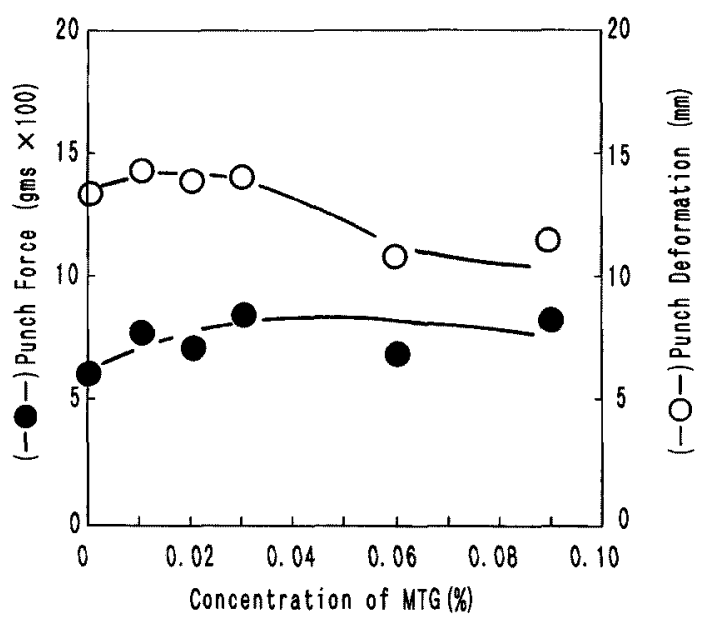

Fig. 6. Functional properties of largehead hairtail surimi gels produced at different enzyme concentrations.

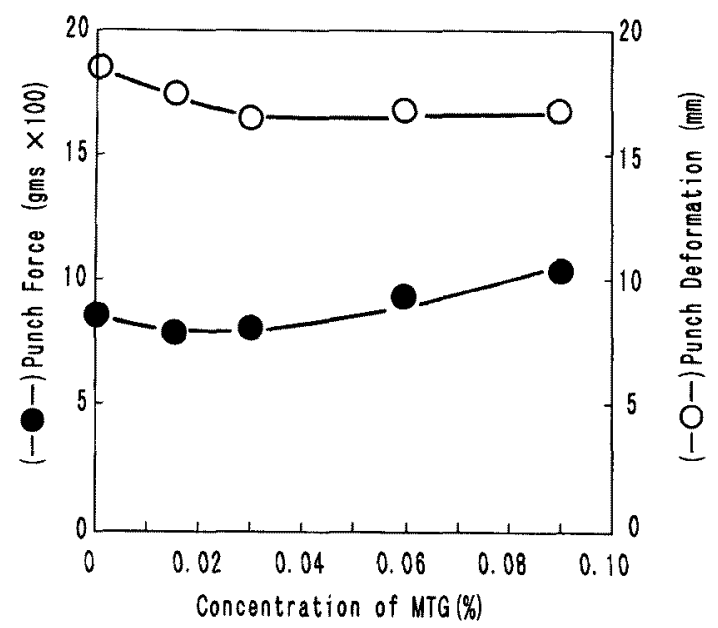

Fig. 7. Functional properties of Hachibiki surimi gels produced at different enzyme concentrations.

\section{Southern Blue Whiting Surimi}

Moisture of the tested southern blue whiting surimi was $76.8 \%$ and $\mathrm{pH} 7.46$. The changes of two textural limits as a result of using several concentrations of MTGase to southern blue whiting surimi is shown in Fig. 8. The value of the punch force of MTGase free gel was over $2000 \mathrm{~g}$, and the value of punch deformation was over $23 \mathrm{~mm}$. The high values of both limits showed that the southern blue whiting surimi sample had the superlative functional quality in the surimi market. The values of punch force increased slightly with the addltion of $0.03 \%$ MTGase, but decreased at higher concentrations. On the measurements of punch deformation, the values of all tested surimi gels decreased with the addition of MTGase.

\section{Discussion}

Present experiments show that the effects of MTGase on the properties of surimi gels varied with each fish species. Though it was reported that the effect of MTGase on the textural properties of Kamaboko gel of walleye pollock ${ }^{\text {ig) }}$ changed by the setting temperature, the results of the present investigations using various kinds of fish species under the setting condition at $30^{\circ} \mathrm{C}$ for $60 \mathrm{~min}$. could be summarized tentatively. For example, the marked increasing effect of MTGase on the punch force was confirmed in the land-processed walleye pollack surimi, and a moderate increasing effect was, confirmed in the surimi samples of white croaker, lizard fish, largehead hairtail, bigeye only a slight and the ship-processed walleye pollack surimi. However, increas on the effects of MTGase on the punch force were observed in the surimi samples of southern blue whiting and hachibiki. Especially, the remarkable rubbery texture of southern blue whiting surimi was lost by the addition of, MTGase.

The accumulated experiences of the processing of

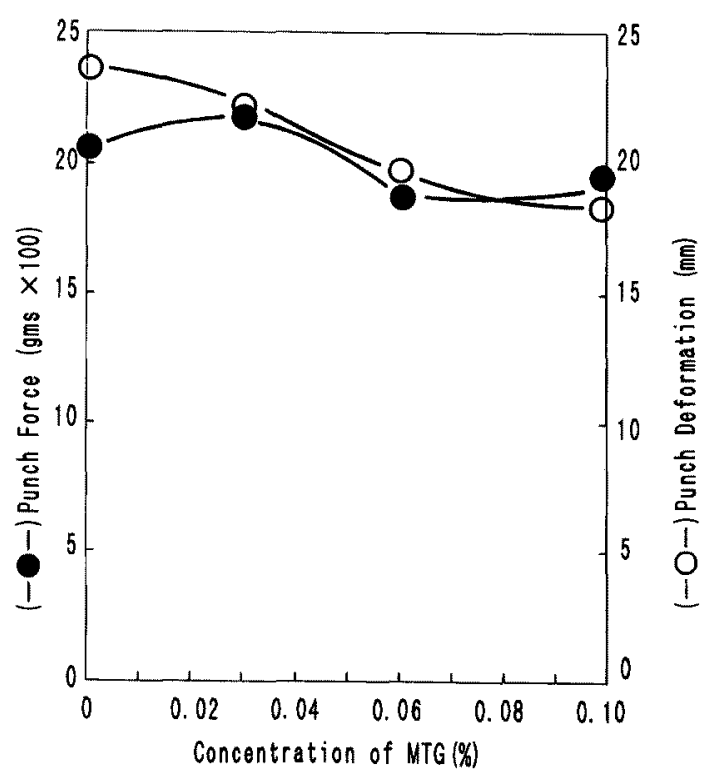

Fig. 8. Functional properties of Southern blue whiting surimi gels produced at different enzyme concentrations. 
Japanese fishery products let us know that each species shows its own characteristics in each process. Because of the above reason, Japanese technologists and fishery scientists have great interests in the species-specificity of raw fish. The characteristic of the present study with various kinds of fish species is to take notice of the species-specificity of raw fish. Many studies on the reactivity, of $\mathrm{Ca}^{2+}$-dependent TGase to the various muscle proteins have been reported by Tsukamasa and Shimizu, 23) Tsukamasa et al. ${ }^{24)}$ Kamath, et al. ${ }^{14)}$ and Chan et al. ${ }^{13)}$ What can be suggested is that these results proved that the rates of reactivity of cross-linking were different according to the source of fish species or animals in general. Recently, Araki and Seki ${ }^{25}$ reported that the content of $\mathrm{Ca}^{2+}$-dependent TGase and the conformational factor of the substrate actomyosin are changed by the species of fish. Moreover, they suggested the importance of the strong relationship between the low level of TGase activity of chum salmon surimi and the high concentration of anserine, which is known as a inhibitor of TGase, in the chum salmon muscle. ${ }^{* 1}$ It is considered satisfactory that the present phenomena with $\mathrm{Ca}^{2+}$. independent MTGase could be concluded from the results of the above reported basic-research. However, there is recognizable differences in the two kinds of walleye pollack surimi, in the present experiment. This results show that the increasing effect of MTGase is not only controlled by the fish species but also by more complicated factors such as freshness of the raw fish.

In the commercial plant, the positive countermeasures against the varied raw fish with complicated factors should be prepared. For instance, the delicate preparation of the food additives including MTGase adjusted to the condition of each raw fish in the surimi plant will be able to be of practical use and useful. In the present experiment, the values of punch deformation decreased with the addition of over $0.03 \%$ MTGase in all tested surimi made from various kinds of fish species. At present, the value of punch deformation is highly appraised by the Kamaboko makers more than the punch force. Considering the above results of the punch test, we recommend that about $0.03 \%$ of the MTGase powder is the desirable concentration of the enzyme for the frozen surimi processing, in general.

Many arguments on the degree of accuracy and the difficulty of analysis of the punch test have, been presented. The accuracy of the data of the present punch test were investigated by using the values of coefficient of variation. In the present punch force measurements, the ranges of the coefficient of variation were from 4.0 to $11.4 \%$. In the punch deformation measurements, the ranges were from 2.7 to $10.7 \%$ as shown, Table 1 . The calculated values from the present data are relatively low. This statistical data enables one to compare the functional properties of MTGase added surimi and MTGase free surimi samples at least semi-quantitatively, and to obtain the sufficient trend curves of the functional changes under each conditions.

In the present preparation of surimi gel for the punch test, the condition of setting was defined at $30^{\circ} \mathrm{C}$ and for $60 \mathrm{~min}$. Because of restrictions in the present experiment, only one setting condition was firmly selected. The setting condition of $30^{\circ} \mathrm{C} \pm 2{ }^{\circ} \mathrm{C}$ for $60 \mathrm{~min}$. was defined in Japanese standards of quality inspection for frozen surimi. ${ }^{* 2}$ Recently, Abe ${ }^{19}$ reported the setting conditions of

Table I. The values of coefficient of varietion of the measured values of punch test

\begin{tabular}{|c|c|c|c|c|c|c|c|}
\hline \multirow{2}{*}{ Fish species } & \multicolumn{7}{|c|}{ Concentration of MTGase (\%) } \\
\hline & 0 & 0.01 & 0.015 & 0.02 & 0.03 & 0.06 & 0.09 \\
\hline \multicolumn{8}{|c|}{ Walleye pollock $^{* !}$} \\
\hline$(\text { P.F. })^{* 2}$ & $8.68 \%$ & $9.68 \%$ & - & $8.26 \%$ & $8.37 \%$ & $9.04 \%$ & $6.73 \%$ \\
\hline$(\text { P.D. })^{* 3}$ & 5.26 & 5.33 & - & 2.40 & 3.41 & 3.80 & 4.55 \\
\hline \multicolumn{8}{|l|}{ White croaker } \\
\hline (P,F,) & 11.00 & 11.38 & - & 9.67 & 8.87 & 9.24 & 8.21 \\
\hline (P.D.) & 6.40 & 8.47 & - & 5.60 & 7.87 & 10.70 & 3.39 \\
\hline \multicolumn{8}{|l|}{ Bigeye } \\
\hline (P.F.) & 5.84 & 4.02 & - & 7.93 & 6.01 & 5.57 & 4.83 \\
\hline (P.D.) & 3.85 & 2.72 & - & 4.48 & 3.91 & 5.61 & 5.10 \\
\hline \multicolumn{8}{|c|}{ Largehead hairtail } \\
\hline (P.F.) & 7.84 & 7.95 & - & 6.69 & 8.15 & 6.08 & 7.44 \\
\hline (P.D.) & 7.52 & 6.34 & - & 2.90 & 7.19 & 2.80 & 7.50 \\
\hline \multicolumn{8}{|l|}{ Lizard fish } \\
\hline (P.F.) & 9.86 & - & 5.32 & - & 7.64 & 10.04 & 8.59 \\
\hline (P.D.) & 5.70 & - & 3.16 & - & 5.03 & 5.66 & 5.48 \\
\hline \multicolumn{8}{|l|}{ Hachibiki } \\
\hline (P.F.) & 9.82 & - & 8.91 & - & 9.14 & 8.24 & 9.22 \\
\hline (P.D.) & 2.73 & - & 4.05 & - & 3.68 & 6.02 & 4.24 \\
\hline
\end{tabular}

Punch force and punch deformation of the surimi gels made from various kinds of fish species.

*1 Land-processed walleye pollock frozen surimi.

*2 Punch force.

*3 Punch Deformation.

The value of coefficient of variation of each sample was calculated with 6 pieces of specimen, and the mean values of each sample were shown in the Figures.

*1 Tsukamasa et al.: Abst. Metg. Japan. Soc. Fisheries Sci., April, 1994, p. (in Japanese).

*2 The standard was notified by Japanese Fishery Agency at April first 1994 (6 Sui Gyo No. 1065) to surimi and kamaboko makers, and was also proposed at the meeting of joint FAO/WHO food standards programme, codex alimentarius commission, as code of practice for frozen surimi, Bergen, Norway, 2-6 May 1994. 
MTGase added Kamaboko gel prepared from the commercial frozen walleye pollock surimi. His data supported that our condition is included in his proper setting condition. The present setting condition is of practical use and useful, especially for surimi of walleye pollock. However, it is well known that the rate of denaturation of muscle protein is varied with fish species by many reported papers ${ }^{26)}$ and also well known that the desirable setting temperature and time are varied with each fish species. ${ }^{3,27)}$ For more detailed information, the studies on the setting conditions of MTGase added surimi made from various fish species is needed, though the present experiment could not offer the related data.

The whiteness of each sample gel was calculated by the optical values of $L^{*}, a^{*}$, and $b^{*}$. However, clear differences were not determined between MTGase added gel and MTGase, free surimi gel in all tested surimi samples (not shown).

The safety of food additives is the most important. Various studies on the introducing covalent, crosslinks into food proteins by transglutaminase have been reported by Cohen et al. $^{4)}$ and many reserchers. ${ }^{5-9)}$ Moreover lately, transglutaminase in fish muscle tissue has become of interest in connection with the setting of surimi, and many related studies have been reported by fishery scientists. ${ }^{10-15}$ ) In general, this research work lets us know that transglutaminase is widely distributed in a natural food materials. The presence of transglutaminase in natural foods which have been eaten by people for a long time support the safety of the enzyme. Fortunately, MTGase is considered as a legal food additive from the standpoint of safety. In Japan, transglutaminase is included in the list of the natural food additives (Notification No. 207 of the Japanese Welfare Ministry 1989), and the use of MTGase is permitted.

\section{References}

1) E. Niwa: Chemistry of surimi gelation. Ch. 16, In "Surimi Technology"' (ed. by T.C. Lanier and C.M. Lee), Marcel Dekker, Inc., New York, 1992, pp. 389-428.

2) M. Okada and M. Nakayama: The effect of oxidants on jelly strength of kamaboko. Nippon Suisan Gakkaishi, 27, 203-208 (1961).

3) W. Simidu: Studies on the muscle of marine animals IV. Nippon Suisan Gakkaishi, 12, 145-172 (1944).

4) I. Cohen, L. Young-Bandala T. E. Blankenberg, G. E. Siefring, and J. Brunar-Lorand; Fibrinoligase-catalyzed cross-linking of myosin from platelet and skeletal muscle. Arch. Biochem. Biophys., 192, 100-111 (1979).

5) K. Ikura, T. Kometani, K. Sasaki, and H. Chiba: Cross-linking of soybean $7 \mathrm{~S}$ and $11 \mathrm{~S}$ proteins by transglutaminase. Agric. Biol. Chem., 44, 2979-2984 (1980).

6) K. Ikura, T. Kometani, K. Sasaki, and H. Chiba: Cross-linking of casein components by transglutaminase. Agric. Biol. Chem., 44, 1567-1573 (1980).

7) L. Kurth: Crosslinking of myosin and casein by the enzyme transglutaminase. Food Teohnology in Australia, 35, Sept., 420-423 (1983).

8) M. Motoki, N. Nio, and K. Takinami: Functional properties of food proteins polymerized by transglutaminase. Agric. Biol.
Chem., 48, 1257-1261 (1984).

9) C. De Becker-Royer, F. Traore, and J. C. Meunier: Polymerization of meat and soybean proteins by human placental calcium-actlvated factor XIII. J. Agric. Food chem., 40, 2055-2056 (1992).

10) N. Seki, H. Uno, N. H. Lee, I. Kimura, K. Toyoda, T. Fujita, and K. Arai: Transglutaminase activity in alaska pollack muscle and it's reaction with myosin B. Nippon Suisan Gakkaishi, 56, 125-132 (1990).

11) Y. Tsukamasa and $Y$. Shimizu: Setting property of sardine and pacific mackerel meat. Nippon Suisan Gakkaishi, 56, 1105-1112 (1990).

12) I. Kimura, M. Sugimoto, K. Toyoda, N. Seki, K. Arai, and T. Fujita: A Study on the cross-linking reaction of myosin in kamaboko "suwari"' gels. Nippon Suisan Gakkaishi, 57, 1389-1396 (1991).

13) J. K. Chan, T. A. Gill, and A. T. Paulson: Cross-linking of myosin heavy chains from cod, herring and silver hake during thermal setting. J. Food Sci., 57, 906-912 (1992).

14) G. G. Kamath, T. C. Lanier, E. A. Foegeding, and D. D. Hamann: Nondisuldide covalent-cross-linking of myosin heavy chain in "setting"" of Alaska pollock and atlantic croaker surimi. J. Food Biochem., 16, 151-172 (1992).

15) S. H. Kim, J. A. Karpenter, , T. C. Lanier, and L. Wicker: Setting response of Alaska pollock surimi compared with beef myofibrils. J. Foods Sci., 58, 531-534 (1993).

16) N. Nonaka, H. Tanaka, A. Okiyama, M. Motoki, H. Ando, K. Umeda, and A. Matsuura: Polymerization of several proteins by $\mathrm{Ca}^{2+}$ independents transglutaminase derived from microorganisms. Agric, Biol. Chem., 5, 2619-2623 (1989).

17) M. Nonaka, S. Sakamoto, S. Toiguchi, H. Kawajiri, T. Soeda, and M. Motoki: Sodium caseinate and skim milk gels formed by incubatlon with microbial transglutaminase. J. Food Sci., 57, 12141218 (1992).

18) Y. P. Huang, K. Seguro, M. Motoki, and K. Tawada: Cross-linking of contractile proteins from skeletal muscle by treatment with microbial transglutamlnase. J. Biochem., 112, 229-234 (1992).

19) Y. Abe: Quality of kamaboko gel prepared from walleye pollack surimi with an additive cntaining transglutaminase. Nippon Suisan Gakkaishi, 60 381-387 (1994).

20) H. Ando, M. Adachi, K, Umeda, A. Matsuura, M. Nonaka, R. Uchino, H. Tanaka, and M. Motoki: Purification and characteristics of novel transglutaminase derived from microorganisms. Agric. Biol. Chem., 53, 2613-2617 (1989).

21) J. E. Folk and P. W. Cole: Mechanism of action of Guinea pig liver transglutaminase, 1. Purification and properties of the enzyme: Identification of a functional cysteine essential for activity. $J$. Biolm Chem., 241, 5518-5525 (1966).

22) K. Toyoda, I. Kimura, T. Fujita, S. F. Noguchi, and C. M. Lee: The surimi manufacturing process. Ch. 4, In "Surimi Technology", (ed. by T. C. Lanier and C. M. Lee), Marcel Dekker, Inc., New York, 1992, pp. 79-112.

23) Y. Tsukamasa and Y. Shimizu: Factors affecting the transglutaminase-associated setting phenomenon in fish meat sol. Nippon Suisan Gakkaishi, 57, 535-540 (1991).

24) Y. Tsukamasa, K. Sato, Y. Shimizu, C. Imai, M. Sugiyama, Y. Minegishi, and M. Kawabata: $\varepsilon$ - $(\gamma$-Glutamyl) lysine crosslink formation in sardine myofibril sol during setting at $25^{\circ} \mathrm{C}$. J. Food Sci., 58, 785-787 (1993).

25) H. Araki and N. Seki: Comparison of reactivity of transglutaminase to various fish actomyosins. Nippon Suisan Gakkaishi, 59, 711-716 (1993).

26) A. Hashimoto, A. Kobayashi, and K. Arai: Thermostability of fish myofibrillar Ca-ATPase and adaptation to enviromental temperature. Nippon Suisan Gakkaishi, 48, 671-684 (1982).

27) Y. Shimizu, R. Machida, and S. Takenami: Species variations in the gel-forming characteristics of fish meat paste. Nippon Suisan Gakkaishi, 47, 95-104 (1981). 